\title{
Sales Tax And Consumer Purchase Decisions
}

Kimberly G. Key (E-mail: keykimb@auburn.edu), Auburn University Lisa L. Scribner (E-mail: scribnerl@uncw.edu), University of North Carolina at Wilmington

\begin{abstract}
This study uses an experimental design to investigate the effect of sales tax on consumer mail order purchase intentions. Economic- and psychology-based theories generate alternative predictions for purchase intentions. Overall the results show that no conclusion can be made that sales tax affects consumer purchase intentions.
\end{abstract}

\section{Introduction}

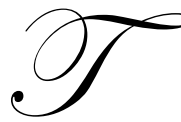

his study investigates the effect of sales tax on consumer mail order purchase decisions. Mail order purchases differ from local retail outlet purchases with respect to sales tax when the mail order seller is not obligated to charge sales tax. When out-of-state businesses do not conduct sufficient business activity within a state, the businesses do not have an obligation to collect and remit the state's sales tax on purchases shipped to in-state customers (e.g., National Bellas Hess 1967 and Quill 1992). In the language of the courts and applicable state statutes, these out-of-state firms lack "nexus" with the purchaser's state. Nexus issues are especially important for direct marketing and mail order because numerous firms have nexus with only a handful of states yet generate sales in nearly all states. The sales tax issue is important to the industry and state tax authorities because there are conflicting views on the effect of sales tax on firm customers. For example, Dow Jones Online News (1997) reports that analysts have debated how the sales tax would affect customers. Some argue that the convenience of mail-order shopping offsets the extra [tax] charge and others predicting a decline in catalog sales.

The primary research question addresses consumer sensitivity to taxes by assessing purchase intentions. The mail order setting is theoretically similar to geographical border settings. Prior research shows significant consumer sensitivity to tax rates for consumers living along state borders (e.g., Fox [1986]). However, in the mail order setting consumers' tax motivated behavior does not depend on consumers living close to a border. Instead, any in state consumer can place an order with an out of state firm (that lacks nexus with the state) and avoid sales tax charges by the vendor. (Goolsbee, 2000) finds that sales taxes have significant effects on Internet purchases, transactions in which state sales tax can also be avoided. However, Adkins and Key (2002) find no statistically significant abnormal returns when investigating a United States Supreme Court case that affected sales tax collection obligations. This study provides additional evidence related to the inconsistent results in prior research.

The second research question examines psychological factors associated with decision making. Price is often included as an explanatory variable in studies of customer perceptions, but little research has examined customer perceptions of separate elements of price. This study considers whether consumers are affected by disclosure of price and tax information or whether standard economic theory holds and disclosure is irrelevant.

Customer perceptions of the sales tax are assessed using an experimental design in which subjects judge their purchase intentions with respect to a mail order product. The product description contains various extrinsic attributes including the separate dimensions of price, sales tax and shipping and handling. The results show that in a scenario that differs only on whether sales tax is charged, there are no statistically significant differences in consumer purchase intention. This result is not consistent with economic theory that predicts there will be differences in purchase intentions because there are differences in the total price that a consumer would pay. In a second scenario, 
separate price elements, cost of item and sales tax, are investigated. Economic theory predicts no difference in consumer purchase intentions because the total price is the same in each manipulation. A psychology-based theory predicts that separating the price elements will reduce purchase intentions. Results are consistent with the economic theory. Overall the results show that no conclusion can be made that sales tax affects consumer purchase decisions.

The paper proceeds by describing the motivation for the study and the institutional setting in Section 2 . Section 3 contains the development and statement of hypotheses. Research design is presented in Section 4, and Section 5 reports the results. Concluding remarks are discussed in Section 6, and Section 7 makes suggestions for future research.

\section{Sales Tax Issues In The Direct Marketing Industry}

\subsection{Prior Research And Motivation}

Prior research shows that differential sales tax rates along state borders distort the location of retail sales along those borders (e.g., Fox [1986] and Walsh and Jones [1988]). In these settings consumers are predicted to shop in lower tax rate jurisdictions when the tax savings is greater than transportation costs and opportunity costs of travel time to obtain the tax savings. Walsh and Jones (1988) report that work in this area shows behavioral responses such that a $1 \%$ increase in the sales tax rate is associated with sales declines ranging from 1 to $10 \%$. Goolsbee (2000) examines the effects of sales taxes on Internet commerce, a setting theoretically similar to the geographical border studies. Internet sales tax issues are the same as the traditional mail order setting issues where orders are phoned or mailed. The sales tax collection obligations do not depend on the customer ordering mechanism. If the firm has nexus with a state, the firm is obligated to collect sales tax from the customer. Results in Goolsbee (2000) show that people who live in high sales tax locations are more likely to make purchases using the Internet. He reports that the tax responsiveness is similar to tax research on retail sales in geographical border areas. The results suggest that applying existing sales taxes to Internet purchases would reduce the number of online buyers by $20-25 \%$ and spending by $25-30 \%$ (Goolsbee, 2000). A limitation of the study is that the data do not reveal whether consumers' Internet transactions actually were subject to sales tax. He assumes all Internet transactions avoid sales tax (page 7). This assumption is almost certainly violated, but the extent of the violation cannot be assessed. ${ }^{1}$ The implication of this violation is that estimates of the reduction in the number of online buyers are likely overstated to some degree. This study's use of an experimental design provides certainty with regard to whether or not sales tax is part of the purchase transaction.

Adkins and Key (2002) examine shareholder reactions to judicial decisions that affect sales tax collection by firms conducting direct marketing activities. The decisions pertain to the Quill case, which is discussed in the next section of the paper. Their results do not indicate statistically significant abnormal returns at event dates. This study uses a research design that is different from both Goolsbee (2000) and Adkins and Key (2002) and can provide additional evidence on those studies' conflicting results.

This study also addresses conflicting industry views with respect to sales tax collection obligations. A representative of Eddie Bauer says the requirement to collect mail-order sales tax from customers in states with which Eddie Bauer has nexus "caused only a 'very slight' drop in sales," but the CEO of a clothes maker in New Mexico says, "Charging the tax could 'severely impact' business," (Milbank, 1997). William Dean, a catalog consultant says, "The bottom line is convenience, ... and the tax isn't much of a factor," yet retail consultant Kurt Barnard states, "Customers will think twice before ordering a costly item from a catalog if a sales tax is to be added" (Wolf, 1997). The study can provide information useful in settling the sales tax collection dispute between state tax authorities and direct marketers by providing some evidence that can be weighed by parties in formulating and advocating their positions. For example, if customers do not perceive sales tax as a deterministic attribute in the mail-order purchase decision, concern by industry members of potential negative ramifications on firm performance could be alleviated to some degree. 


\subsection{Sales Tax And Out-Of-State Businesses}

Sales tax is imposed on the purchase price of most retail goods. ${ }^{2}$ The tax is incurred by the purchaser, but the seller has an agency-type obligation to the state to collect and remit the sales tax collected from customers if the seller has nexus with the state. Nexus is a concept that defines the minimum level of business activity in a state that must exist in order for the state to have jurisdiction over and taxing authority with respect to the business. Therefore, a business without nexus to a state can make sales to customers in that state without an obligation to collect and remit sales tax. ${ }^{3}$ These sales tax nexus issues are particularly relevant to direct marketers as the nature of the business is such that many firms generate sales in states with which the firms do not have nexus. However, some firms have operations in all or nearly all fifty states, which creates nexus, so the firms are obligated to collect sales tax from most of their mail-order customers. ${ }^{4}$ The difference in the number of states with which sample firms have nexus allows for tests that reflect the different tax collection obligations.

Nexus standards have Constitutional underpinnings in the Commerce Clause and Due Process Clause, which impose limits on taxing powers of states. In Quill, North Dakota sought to impose tax collection responsibilities on an out-of-state mail-order office supply business that had no offices, warehouses, or employees in the state. The facts are indistinguishable from those in a 1967 U.S. Supreme Court decision, National Bellas Hess, but the North Dakota state court did not follow the precedent of the 1967 case stating that "tremendous social, economic, commercial, and legal innovations of the past quarter century... rendered the [1967] holding obsolete." The U.S. Supreme Court overruled the state court and maintained the existing physical presence standard for nexus. Thus, vendors who solicit business through catalogs, flyers, advertising in national periodicals, and telephone calls and who deliver merchandise to customers by mail or common carrier lack "substantial nexus" with the state and may not be required by the state to collect and remit customer sales tax (Quill). The increased visibility of the sales tax issue due to the judicial activity motivates this study's examination of customer perceptions in a controlled test setting.

\section{Hypothesis Development}

The general framework for investigating customer perceptions of sales tax contrasts decision making predictions from an economic perspective of the consumer as a rational, utility maximizer with those from a psychological perspective. Analyses of decision making commonly distinguish between risky and riskless choices (Kahneman and Tversky, 1984). This study investigates riskless choices, which have received less attention from accounting researchers than have risky choices. ${ }^{5}$ Kahneman and Tversky (1984) describe a typical riskless decision as one that concerns the acceptability of a transaction in which a good or service is exchanged for money. The experimental design of this study entails the use of transactions in which a good, a book, purchased via mail order is exchanged for money.

The first hypothesis investigates whether sales tax affects the purchase intentions of a customer, all other things being equal. Economic theory of consumer choice predicts that, from the viewpoint of the consumer, a tax on a good increases the perceived price (Varian, 1990). "It is just as if the price of the good has increased by the tax amount" (page 86). A psychology-based prediction is not offered. ${ }^{6}$ Based on economic theory, the first hypothesis is as follows:

H1: Customer purchase intentions are lower when a sales tax is imposed on a mail-order purchase transaction than when no sales tax is imposed.

Hypothesis 2 investigates whether disclosure of the tax information affects purchase intentions. Standard economic theory does not allow for separate components of price such as sales tax to affect perceptions or decision making. As stated above, a tax on a good increases the perceived price. Therefore, economic theory of consumer choice predicts no difference in purchase intentions when total cost is constant but tax disclosure varies. 
Thaler (1985), however, states that in some situations, a mental accounting system causes the violation of a simple economic principle. With respect to marketing, Thaler (1985) raises questions such as, "How would a seller want to describe (frame) the characteristics of a transaction?" and "Which attributes should be combined and which separated?" Thaler (1985) describes a process of analyzing transactions with compound outcomes comprised of a good and a price, which can be extended to multiple goods and/or prices. Joint outcomes are valued either jointly/integrated or separately/segregated. Four possible combinations are considered, with "multiple losses" the relevant scenario for the sales tax investigation because integration is preferred when there are multiple losses (Thaler, 1985). ${ }^{7}$

Mathematically, the integration of multiple losses predicts the following value functions for a good in order to investigate the sales tax disclosure issue:

$v(p+p * t)>v(p)+v(p * t)$

where $\mathrm{v}=$ customer value or utility function, $\mathrm{p}=$ sales price of good, and $\mathrm{t}=$ sales tax rate. Therefore, from a psychological perspective, customer value or utility is higher and purchase intentions are assumed to be higher when a single, tax-inclusive price is disclosed versus separate statement of the tax. Note the left-hand side represents "tax included" sales tax disclosure, while the right-hand side depicts typical existing sales tax disclosure. The economicand psychology-based hypotheses are specified, respectively, as follows:

$\mathbf{H 2}_{\mathrm{A}}$ : Customer purchase intentions are not different when sales tax is included in the price than when the sales tax is separately stated.

$\mathbf{H 2}_{\mathrm{B}}$ : Customer purchase intentions are higher when sales tax is included in the price than when the sales tax is separately stated.

\section{Research Design}

Customer purchase intentions are assessed in an experimental design that examines a hypothetical mailorder purchase decision. This section describes the mail-order product, states the dependent variable measure, and identifies subjects. The appendix includes the experimental materials.

The product description presented to subjects is a book that is being considered for purchase for a friend or relative. Subjects are told to assume that they are genuinely interested in purchasing a book for a friend or relative as a gift and that the book topic is relevant to the friend or relative. Information concerning the book is the same for all subjects. It is a collector's edition, hardcover, 450 pages, professionally bound, and has color photos. The last bulleted attribute of the book is price, which minimally contains three items: the retail price, shipping and handling (constant at \$3.00), and a total. Tax information provided in the description depends on the respective hypothesis. When a specific state tax rate is used in the manipulation, North Carolina rates are identified or assumed because the subjects live in North Carolina.

The dependent variable is the subject's purchase intentions. The first question to which subjects respond is "How likely is it that you would buy this book for your friend or relative if you wanted to purchase a book?" The question is answered using a seven-point ascending scale weighted from "very unlikely" to "very likely."

The subjects for the study were recruited from Masters in Business Administration and Masters in Accountancy programs. The sample consists of 67 students who agreed to participate voluntarily. The subjects range in age from 21 to 45 with a mean of 28 years old. Fifty-six percent of the sample is male and almost all subjects (93\%) are from the United States. Purchasing via mail order is not unfamiliar to this group of subjects; in fact, $88 \%$ of them have purchased merchandise through this distribution outlet. 


\section{Results}

\subsection{Manipulation Checks}

Manipulation checks indicate for all conditions that subjects interpreted or understood information as expected. ${ }^{8}$ Conditions are as follows: 1 ) sales tax included/not disclosed (assumed 6\%), 2) sales tax disclosed at 6\%, 3) no sales tax. Hypothesis 1 compares Conditions 2 and 3. Hypothesis 2 compares Conditions 1 and 2. With respect to Hypothesis 1, 95\% of subjects in the no sales tax condition correctly understood that sales tax would not be charged, and 95\% of subjects in the sales tax disclosed condition reported the correct sales tax of 6\%. For purposes of testing Hypothesis 2, a tax rate of $6 \%$ applies to both sets of subjects. When asked the tax rate incurred, subjects in Condition 1 report a mean of 5.70, and subjects in Condition 2 report a mean of 5.86. There is no statistical difference between the two groups $(\mathrm{t}=.67, \mathrm{p}=.51)$.

\subsection{Demand Check}

The final question in the post-test questionnaire is, "Finally, what do you believe is the purpose of this study?" None of the subjects correctly identified the specific hypotheses. Several subjects correctly ascertained the general purpose of the study. However, this general knowledge is assumed to be due to several direct post-test questions that address sales tax and mail-order issues. Subjects were instructed not to go back to any previous pages, so it is unlikely that the dependent variable and manipulation check information is contaminated. Therefore, all subjects are included for further analysis.

\subsection{Tests of Hypotheses}

Table 1 reports means and standard deviations of purchase intentions by conditions. The table also summarizes the statistical comparisons that are made for purposes of testing the two hypotheses. The mean purchase intentions range from 4.00 to 4.38 across the three conditions, where $1=$ very unlikely and $7=$ very likely. These means show the subjects on average display a slightly positive tendency to purchase the book.

Hypothesis 1 states that purchase intentions are less likely when sales tax is imposed on a mail-order transaction because the cost of the book is higher. This hypothesis is intended to capture the existing state of nature regarding the sales tax issue. Therefore, responses from subjects in the "no sales tax" condition are compared to subjects" responses in the "sales tax included and disclosed," Conditions 3 and 2 as reported in Table 1. The hypothesis predicts that purchase intentions are higher for Condition 3 than for Condition 2. Inconsistent with the prediction, the Condition 3 mean (4.00) is not higher than the Condition 2 mean (4.17).

The second hypothesis concerns the effect of the disclosure of the sales tax on purchase intentions when the tax rate is constant. Because the total price is the same, the economics-based prediction states that purchase intentions should not be different when sales tax is included in the sales price or when the sales tax is separately disclosed (Condition 1 mean equal to Condition 2 mean). The psychology-based theory suggests customers' purchase intentions are higher when sales tax is included in the price than when the sales tax is disclosed separately (Condition 1 mean greater than Condition 2 mean). The difference in purchase intentions between subjects in Condition 1 (mean $=4.38)$ and those in the Condition $2($ mean $=4.17)$ is not statistically significant $(\mathrm{t}=.43, \mathrm{p}=.67)$. Therefore, the data are consistent with economics-based Hypothesis $2_{\mathrm{A}}$ and not with Hypothesis $2_{\mathrm{B}}$.

\subsection{Conclusions And Implications}

The conclusion from the Hypothesis 1 test is that sales tax appears to have no effect on purchase intentions. This result is consistent with opinions of some interested parties who state the sales tax is not much of a factor in the purchase decision. Direct marketers could focus their efforts away from fighting against sales tax collection requirements and toward securing from states as many protections and benefits as possible in exchange for collecting the sales tax. Implications to direct marketers are subject to caveats that the sample size is small and purchase intentions in an experimental setting may differ from a real purchase. 
Hypothesis 2 addresses alternative sales tax disclosures firm managers could adopt. No differences in purchase intentions are detected when the implicit or explicit tax rate is constant. Therefore, the disclosure choice and related design of pricing information appears not to matter, and economic theory that predicts customer utility is a function of the total price incurred holds.

\section{Conclusion}

The purpose of this study is to provide evidence on customer perceptions of the effect of sales tax collection obligations on direct marketing activities. Data do not show customers appear to perceive the sales tax to be an important enough factor to change their decision making with respect to purchase intentions. A potential limitation to this study is that the book is a relatively low-priced item. Therefore, the dollar amount of sales tax could be considered an insignificant expense. A further limitation is that no picture of the product was provided in the experimental manipulation as would normally occur in a catalog purchase decision.

\section{Suggestions For Future Research}

Future research could investigate whether greater differences are observed in purchase intentions when the price of an item is much higher. For example, consumers purchasing a computer could be subject to sales tax in excess of one hundred dollars. Future work can also extend research that considers whether using tax terminology affects subjects' preferences. Kachelmeier, Limberg, and Schadewald (1991) state that whether subjects modify their behavior to the word "tax" has been open to question. Decision making when an experiment clearly deals with tax evasion may reflect values subjects associate with tax terminology rather than intended experimental manipulations (Alm, McClelland, and Schulze, 1992). An examination of the issue in the sales tax setting should provide direct evidence on taxpayers' disinclination to pay tax because, unlike individual income tax compliance decision making, the sales tax setting does not entail evasion. ${ }^{9}$

\section{References}

1. Adkins, N. and K.G. Key. 2002. "Shareholder Reactions to Judicial Decisions Affecting Sales Tax and Direct Marketing Activities," 18 Journal of Applied Business Research 3: 23-31.

2. Alm, J., G.H. McClelland, and W.D. Schulze. 1992. Why Do People Pay Taxes? Journal of Public Economics 48: 21-38.

3. Barrett, P. 1992. Justices Rebuff States on Taxing Mail-Order Sales, The Wall Street Journal, Dow Jones \& Company, Inc., May 26, 1992.

4. Dow Jones Online News. 1997. Talks Continue, But Catalog Sales Tax Issue Addles Customers. Dow Jones \& Company Inc., November 7, 1997.

5. Elsasser, G. 1992. High Court Clears Way for Taxing Mail Orders. Chicago Tribune, May 27, 1992.

6. Fox, W. 1986. "Tax Structure and the Location of Economic Activity Along State Borders," National Tax Journal 39: 387-401.

7. Goldreich, S. 1997. Mail-Order Retailers Deny Agreement Near on Taxes. Knight-Ridder Tribune Business News, November 7, 1997.

8. Goolsbee, A. 2000. In a World Without Borders: The Impact of Taxes on Internet Commerce, 90 Quarterly Journal of Economics 2: 271-276.

9. Hamilton, A. 1997. Electronic Commerce - Knee-Deep in Nexus: News Analysis. State Tax Notes, May 26, 1997: 1597:1600.

10. Johnston, D. 1997a. Mail-Order Group Agrees to Collect State Sales Tax. New York Times, November 6, 1997.

11. Johnston, D. 1997b. Angry Customers Hinder Mail-Order Tax Accord. New York Times, November 7, 1997.

12. Kachelmeier, S.J., S.T. Limberg, and M.S. Schadewald. 1991. A Laboratory Market Examination of the Consumer Price Response to Information about Producers' Prices and Profits. The Accounting Review 66: 694-717. 
13. Kahneman, D., J.L. Knetsch, and R.H. Thaler. 1986. Fairness and the Assumptions of Economics. The Journal of Business 59: S285-S300.

14. Kahneman, D. and A. Tversky. 1979. Prospect Theory: An Analysis of Decision Making Under Risk. Econometrica 47: 263-291.

15. Kahneman, D. and A. Tversky. 1984. Choices, Values, and Frames. American Psychologist 38: 341-350.

16. Meade, J. 1990. The Impact of Capital Gains Tax Regimes on the Lock-In Effect and New Risky Investment Decisions. The Accounting Review 65: 406-431.

17. Milbank, D. 1997. Trade Group, Authorities in Talks to Settle Issue of Mail-Order Tax. The Wall Street Journal, Dow Jones \& Company, Inc., November 7, 1997: B4.

18. National Bellas Hess, Inc. v. Department of Revenue of Illinois, 386 US 753, 87 S.Ct. 1389 (1967).

19. Outslay, E.O. 1995. "The State of Behavioral Tax Research: An Editor's Perspective. In Behavioral Tax Research: Prospects and Judgment Calls ed. Jon S. Davis. American Taxation Association, Sarasota, FL.

20. Quill Corporation v. North Dakota, 504 US 298, 112 S.Ct. 1904 (1992).

21. Savage, D. 1992. Court Voids State Mail-Order Tax. Los Angeles Times, The Times Mirror Company, May 27, 1992.

22. State Tax Notes. 1997. Draft of Agreement on Sales Tax by Marketers. November 17, 1997: 1273-1279.

23. Thaler, R. 1985. Mental Accounting and Consumer Choice. Marketing Science 4: 199-214.

24. Varian, H. R. 1990. Intermediate Microeconomics: A Modern Approach ( $2^{\text {nd }}$ edition), W.W. Norton \& Company, New York, New York.

25. The Wall Street Journal. 1992. Negotiation, Not Legislation, is Next for the States and Direct Marketers, June 2, 1992, Dow Jones \& Company, Inc.

26. Walsh, M. and J. Jones. 1988. "More Evidence on the "Border Tax" Effect: The Case of West Virginia, 1979-84," National Tax Journal 41: 261-265.

27. Wartick, M.L. 1994. Legislative Justification and the Perceived Fairness of Tax Law Changes: A Referent Cognitions Theory Approach. Journal of the American Taxation Association 16: 106-123.

28. Wolf, R. 1997. Catalog Customers to Face a Costly Question: Sales Tax. Dow Jones Online News, Dow Jones \& Company, Inc., November 6, 1997.

\section{Endnotes}

${ }^{1}$ Every firm has nexus with at least one state, and the majority of states imposed sales and use tax. Therefore, firm sales are very likely to be subject to sales tax collection in at least one state.

${ }^{2}$ The presentation of the concepts focuses on retailers because the study investigates direct marketers. Note that a broader set of businesses can have obligations to collect sales tax.

${ }^{3}$ Technically a customer who makes purchases on which no sales tax is paid has a use tax obligation to the state. Theoretically, then, the use tax fully captures sales tax that is not collected by out-of-state businesses. However, use tax collections are far below the sales tax amounts for which the use taxes should substitute. The reasons are likely a combination of (1) a lack of knowledge of use tax obligations on the part of the purchaser and (2) a low probability that an informed decision not to comply with use tax will be detected and punished. Estimates are that $\$ 3$ billion in potential tax is not being collected (Milbank, 1997).

${ }^{4}$ For example, Eddie Bauer clothing is sold both by catalog and in retail store outlets throughout the United States. The in-state retail operations create nexus with a state, so mail-order sales to customers within the state are subject to sales tax collection by Eddie Bauer.

${ }^{5}$ For example, prospect theory is a descriptive theory of decision making under uncertainty developed by Kahneman and Tversky (1979) that is often contrasted with expected utility theory. Outslay (1995) cites tax research that tests prospect theory.

${ }^{6}$ For example, the nature of tax is such that consumers may have a general disinclination to pay a tax. On the other hand, the tax may be perceived as an unavoidable and irrelevant transaction cost.

7 Thaler (1985) uses the following multiple losses example: "One desirable feature of credit cards is that they pool many small losses into one larger loss and in so doing reduce the total value lost." 
${ }^{8}$ Pilot testing resulted in additional information being provided in the experimental designs because it was unclear if subjects in Conditions 3, 4, and 5 fully understood critical elements in the manipulations. Manipulation checks were also reworded.

${ }^{9}$ Meade (1990) faces this issue and states that disguising a capital gain tax as a management fee is done in part to reduce the likelihood of introducing into the research the subjects' predisposition toward tax. Alm, et. Al. (1992) address this issue in a study of individual tax compliance by running experiments with both "loaded" tax terms and with "neutral" terms and find identical results across both treatments (Alm, et. Al., 1992), which lessens concerns of terminology effects.

Table 1

Results For Experimental Tests

\begin{tabular}{|c|c|c|c|}
\hline & $\begin{array}{c}\text { Condition 1: } \\
\text { Sales tax included } \\
\text { but not disclosed* }\end{array}$ & $\begin{array}{c}\text { Condition 2: } \\
\text { Sales included and } \\
\text { disclosed } \\
(\text { rate }=6 \%)\end{array}$ & $\begin{array}{l}\text { Condition } 3 \text { : } \\
\text { No sales tax }\end{array}$ \\
\hline \multicolumn{4}{|l|}{$\begin{array}{l}\text { Purchase } \\
\text { intentions: }\end{array}$} \\
\hline Mean & 4.38 & 4.17 & 4.00 \\
\hline (std. Dev.) & (1.64) & $(1.71)$ & $(1.83)$ \\
\hline \# of subjects & $\mathrm{n}=24$ & $\mathrm{n}=24$ & $\mathrm{n}=19$ \\
\hline \multicolumn{4}{|c|}{$*$ Assumed North Carolina rate $=6 \%$. } \\
\hline
\end{tabular}

Hypothesis 1:

Condition $3>$ Condition 2; results not consistent with prediction Hypothesis 2:

Condition $1>$ Condition 2 (psychology theory); results not consistent with prediction (p-value $=.67$ )

Condition 1 = Condition 2 (economic theory); results consistent

\section{Appendix \\ Condition 1}

PLEASE READ ALL OF THE INFORMATION AND EACH QUESTION VERY CAREFULLY. ANSWER EACH QUESTION TO THE BEST OF YOUR ABILITY.

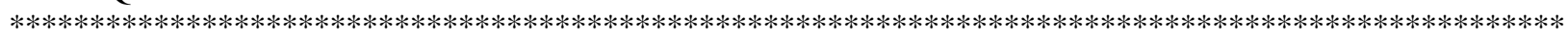

You are being requested to respond to certain questions and statements about the product, a book. Please assume that you are genuinely interested in purchasing a book for a friend or a relative as a gift. Also assume the topic of the book is relevant to your friend or relative. The following is a description from a mail-order company that has operations in many states and ships to consumers in many states. The description is from the most recent nationwide catalog.

Book:

- Collector's Edition

- Hardcover

- 450 pages

- Professionally bound

- Color photos

- Price

$\$ 50.00$ (NC sales tax included)

3.00 shipping and handling

$\$ \overline{53.00}$ Total 
For the book described on the previous page, please respond to the following statements by circling the number that best expresses your feelings.

1. How likely is it that you would buy this book for your friend or relative if you wanted to purchase a book?

$$
\begin{array}{lllllllll}
\text { Very unlikely } & 1 & 2 & 3 & 4 & 5 & 6 & 7 & \text { very likely }
\end{array}
$$

2. The overall quality of this book is:

$\begin{array}{lllllllll}\text { very low } & 1 & 2 & 3 & 4 & 5 & 6 & 7 & \text { very high }\end{array}$

3. The overall value of this book is:
very low
12

2

3

4
$5 \quad 6$
$7 \quad$ very high

4. The total price for this book is:

$\begin{array}{lllllllll}\text { very unfair } & 1 & 2 & 3 & 4 & 5 & 6 & 7 & \text { very fair }\end{array}$

5. Please list your thoughts about the product described on the previous page.

\section{Condition 2}

PLEASE READ ALL OF THE INFORMATION AND EACH QUESTION VERY CAREFULLY. ANSWER EACH QUESTION TO THE BEST OF YOUR ABILITY.

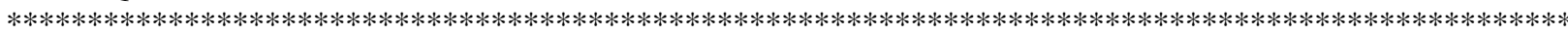

You are being requested to respond to certain questions and statements about the product, a book. Please assume that you are genuinely interested in purchasing a book for a friend or a relative as a gift. Also assume the topic of the book is relevant to your friend or relative. The following is a description from a mail-order company that has operations in many states and ships to consumers in many states. The description is from the most recent nationwide catalog.

Book:

- Collector's Edition

- Hardcover

- 450 pages

- Professionally bound

- Color photos

- Price

$\$ 47.25$

$2.756 \% \mathrm{NC}$ sales tax

3.00 shipping and handling

$\$ 53.00$ Total 


\section{Condition 3}

PLEASE READ ALL OF THE INFORMATION AND EACH QUESTION VERY CAREFULLY. ANSWER EACH QUESTION TO THE BEST OF YOUR ABILITY.

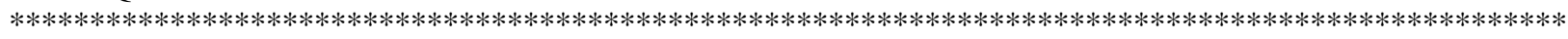

You are being requested to respond to certain questions and statements about the product, a book. Please assume that you are genuinely interested in purchasing a book for a friend or a relative as a gift. Also assume the topic of the book is relevant to your friend or relative. The following is a description from a mail-order company that has operations in many states and ships to consumers in many states. The description is from the most recent nationwide catalog.

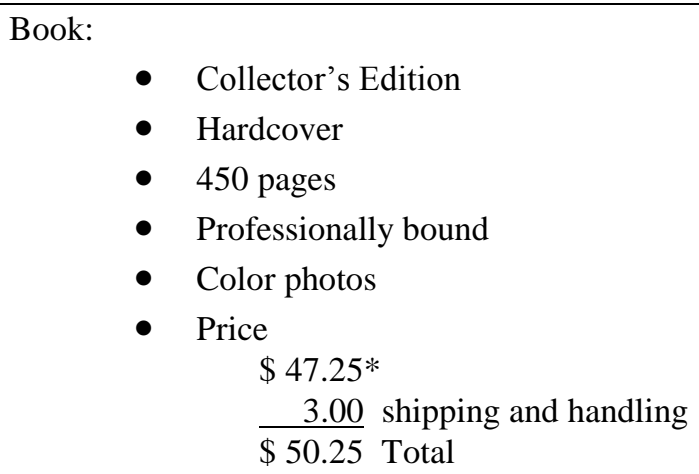

* Residents of Wisconsin (5\%) and Illinois (6.25\%) please add applicable sales tax to this price.

\section{Manipulation Checks And Post-Test Questionnaire}

6. If you were to purchase the book in this study, is a sales tax charged, and if yes, what is the rate?

7. Are you a U.S. Citizen? $\quad$ Yes $\quad$ No (Please circle one.)

If not, from which country are you?

8. What is the highest level of formal education you have completed?

$\begin{array}{ll} & \text { High School } \\ \text { Some College } \\ \text { Bachelor's Degree } \\ \text { Some Graduate School } \\ \text { Graduate School }\end{array}$

9. What is your approximate annual income level (you and your spouse - if applicable)?

Less than $\$ 20,000$
$\$ 20,000-\$ 40,000$
$\$ 40,001-\$ 60,000$
$\$ 60,001-\$ 80,000$
$\$ 80,001-\$ 100,000$
Over $\$ 100,000$

10. What is your age?

11. Please circle your gender:

Male Female 
12. Please circle your marital status:

Single

Married

13. Do you ever purchase any items via mail order? If NO, go to \#21.

14. How many items do you purchase via mail order in a typical year? (check one) less than 1 $1-2$ 3-6 7 or more

15. What types of items have you purchased via mail order? (Check all that apply)

\begin{tabular}{|c|c|}
\hline books & clothing \\
\hline food/beverages & gardening supplies \\
\hline $\begin{array}{l}\text { health/fitness equipment } \\
\text { music/videos }\end{array}$ & $\begin{array}{l}\text { outdoor recreation supplies } \\
\text { household items }\end{array}$ \\
\hline other (please specify) & \\
\hline
\end{tabular}

16. What is the main reason you purchase items through the mail instead of at a local retail outlet?

17. Are there any other reasons? If so, please specify.

18. What is the one thing you like least about shopping through the mail?

19. Do most of the mail-order companies from which you purchase charge you sales tax?

\section{If YES, go to \#21.}

$$
\text { Yes No Unsure }
$$

20. Would your purchase behavior change if mail order companies began charging sales tax on your items?

$$
\text { Yes No Unsure }
$$

If yes, how?

21. Finally, what do you believe is the purpose of this study? 
Notes 


\section{Do Not Print This Page !!}

${ }^{1}$ Every firm has nexus with at least one state, and the majority of states imposed sales and use tax. Therefore, firm sales are very likely to be subject to sales tax collection in at least one state.

${ }^{2}$ The presentation of the concepts focuses on retailers because the study investigates direct marketers. Note that a broader set of businesses can have obligations to collect sales tax.

${ }^{3}$ Technically a customer who makes purchases on which no sales tax is paid has a use tax obligation to the state. Theoretically, then, the use tax fully captures sales tax that is not collected by out-of-state businesses. However, use tax collections are far below the sales tax amounts for which the use taxes should substitute. The reasons are likely a combination of (1) a lack of knowledge of use tax obligations on the part of the purchaser and (2) a low probability that an informed decision not to comply with use tax will be detected and punished. Estimates are that $\$ 3$ billion in potential tax is not being collected (Milbank, 1997).

${ }^{4}$ For example, Eddie Bauer clothing is sold both by catalog and in retail store outlets throughout the United States. The in-state retail operations create nexus with a state, so mail-order sales to customers within the state are subject to sales tax collection by Eddie Bauer.

${ }^{5}$ For example, prospect theory is a descriptive theory of decision making under uncertainty developed by Kahneman and Tversky (1979) that is often contrasted with expected utility theory. Outslay (1995) cites tax research that tests prospect theory.

${ }^{6}$ For example, the nature of tax is such that consumers may have a general disinclination to pay a tax. On the other hand, the tax may be perceived as an unavoidable and irrelevant transaction cost.

7 Thaler (1985) uses the following multiple losses example: "One desirable feature of credit cards is that they pool many small losses into one larger loss and in so doing reduce the total value lost."

${ }^{8}$ Pilot testing resulted in additional information being provided in the experimental designs because it was unclear if subjects in Conditions 3, 4, and 5 fully understood critical elements in the manipulations. Manipulation checks were also reworded.

${ }^{9}$ Meade (1990) faces this issue and states that disguising a capital gain tax as a management fee is done in part to reduce the likelihood of introducing into the research the subjects' predisposition toward tax. Alm, et. al. (1992) address this issue in a study of individual tax compliance by running experiments with both "loaded" tax terms and with "neutral" terms and find identical results across both treatments (Alm, et. al., 1992), which lessens concerns of terminology effects. 